\title{
On the Application of Image Scheme Theory to the English Vocabulary Teaching
}

\author{
Guiyun Guan
}

Northwest Minzu University, Lanzhou, Gansu 730030, China

839709195@qq.com

\begin{abstract}
Vocabulary is the core of language learning, so English vocabulary is of paramount importance. Researchers have been studying for many years to find out effective methods of remembering words, therefore, image schema theory emerges as the time requires. Image schema theory is helpful for students to remember words profoundly and lastingly, but it is often ignored in the teaching process because teachers have to spend more time preparing for their classes if they choose the method to explain the meanings and uses of words. The paper takes advantage of some examples to illustrate the application of the theory to English vocabulary teaching, hoping to popularize the method and make it helpful for students to remember words more effectively.
\end{abstract}

Keywords: image schema theory, English words teaching, application

\section{意象图式理论在英语词汇教学中的应用}

\author{
关桂云
}

西北民族大学, 兰州, 甘肃, 中国

839709195@qq.com

摘要: 词汇是语言学习的核心, 所以英语词汇是英语学习的重中之重。多年来学者们一直探究有效的 词汇记忆方法, 而意象图式法就应运而生。意象图式法虽然可以让学生对于所学词汇记忆深刻, 有助 于学生的长期性词汇记忆, 但是由于该法对于教师备课无疑增添了巨大的工作量而在教学中往往被忽 视。本文主要对意象图式法进行介绍并以实例对意象图式法在英语教学中的应用做出指导, 以期该法 在英语词汇教学中的广泛应用, 帮助学生能更有效地记忆单词。

关键词: 意象图式法; 英语词汇教学; 应用

\section{1.导入}

著名的语言学家威尔金斯(D.A.Wilkins)(1972)在《语 言教学中的语言学》(Linguistics in Language Teaching) 中提到“没有语法, 很少内容可以传达; 没有词汇就什 么内容都传达不了。”(Without grammar, very litter can be conveyed; without vocabulary, nothing can be conveyed." 而另一位伟大的语言学家 Harmer（1991）认为“词汇是 语言的器官和血液”(“Vocabulary constitutes the crucial organ and blood of linguistics"), 词汇能力是语言交际能 力的核心, 它决定着语言交际能力 (Meara, 1996), 所 以词汇是语言学习的最基础也是最重要的部分, 对于词 汇的研究也就成为语言学研究的核心。

虽然词汇在语言中的重要性有目共睹, 但是“对于 大多数中国学生来说, 词汇是他们学习过程中很难攻克 的堡垒”, 主要原因是英语基础薄弱和单词记忆方法不
得当(黄振远，2001)。近些年来随着英语教学经验积 累, 很多研究者提出了不同的词汇记忆方法, 如联想记 忆法、构词记忆法、自然拼读记忆法等, 学生们对这些 记忆法多少都有所了解，但是对于意象图式法记忆单词 却少有耳闻。

\section{2.意象图式的定义}

认知语言学认为, “认知”这一过程可公式化为: 现实 一互动体验一意象图式一范畴一概念、意义一语言。(王 寅，2007）而互通体验、意象图式、范畴、概念和意义 都属于认知部分, 所以该方程式可以简化为: 现实一认 知一语言, 而这也是认知语言学的核心原则, 也就是说 语言是建立在人们对现实世界进行“互动体验”和“认知 加工”的基础上。（王寅，赵永峰，2016:212.）而意象 图式作为一种重要的认知方式, 是大脑认知最基本、最 直接的部分。 
“意象”通常被看作是一种心理表征, 具体指在没有 外界具体实物刺激的情况下, 人们头脑里或心智中存在 的关于某人或某物印象或形象（王寅，2007），“图式” 一词最先是由德国哲学家 Immanuel Kant 在 1781 年提 出, 他认为图式一词是将认知 (perception) 与构想 (conception)联系在一起。 (Amant, et al., 2002) Jean Piaget 皮亚杰在其书中《孩子的语言与思维》(1988)中 提到了“图式”一词, 指人们为了应付某一特定情境而产 生的认知结构, 它源于动作行为。

意象图式理论 (image schema theory) 是由莱考夫 （Lakoff）与约翰逊（Johnson） 在 1980 年将“意象” 与“图式” 结合, 在概念隐喻理论中被提出来, 是认知语 言学中的一个重要理论。符号学家皮尔斯认为, “意象 是事物成分的心理表象, 图式是事物关系的心理表象”。 萨伊德说: “意象图式是认知语义学理论中概念构造的 重要形式。它们是基于我们在世界里的存在、行动、感 受环境、运动身体、发力和受力等经验而形成的基本的 概念构造, 我们可以用它来组织更抽象领域的思想。” (张维鼎, 2007) “话语的理解活动是在图式指导下完 成的，是激活或建构合适的图式并填充新信息的过程” (周明强, 2004)。基本的意象图式包括: 容器 (container)、路径(path)、连接(link)、上-下(up-down_远 近 (near-far)、部分一整体 (part-whole)、中央一边缘 (center-periphery)等, 它们的结合可构成更为复杂的意 象图式。因此, 意象图式实际上就是人们对客观世界进 行感知, 然后在大脑中形成一种具有空间运动关系的图 式。在我国对意象图式理论的研究起始于本世纪初, 近 些年来有较多的学者关注与意象图式理论在词汇教学 上的应用。

\section{3.意象图式理论在大学英语词汇教学中的应 用}

\section{1 意象图式理论在空间类介词中的应用}

空间类介词如 in, on, over, out, under, above 等 由于其广泛地使用性和多义性一直以来都是认知语言 学研究的重点领域。由于意象图式在概念域的映射(尤 其是空间隐喻) 中起着重要的作用 (Ungerer, 2018), 所 以使用意象图式理论对这些空间类介词进行解释, 将达 到事半功倍。Lakoff (1987) 通过使用了 24 个意象图 式研究 over 的意义。在 Brugman 研究的基础上, Lakoff 提出了介词的网络模型。在网络模型中, 介词有个核心 意义，而其他意思都是从中央意义中演化而来。有人 (Lindsromberg，1996）使用意象图式理论对 on 的意 义研究, 也有(Tyler \& Evans, 2003)对 over 的意象图式 进行研究。在我国陈晓湘与许银 (2009) 的实验比较了 以意象图式为基础和以翻译为基础的两种词义教学法 对 on, over, above 三个多义介词的习作效果, 结果显示 前者的教学效果明显优于后者。陈翠翠 (2019) 使用意 象图式理论通过空间对空间的逆移动、空间到时间的转
换、空间到抽象的转换三个方面对介词 from 的意义进 行讲解。岳好平等 (2019) 以意象图式中隐喻拓展理论 为指导从空间域拓展到时间域、状态域、范围域、方式 域再到其他域对介词 in、on、at 进行分析。可以说使 用意象图式理论对空间类介词解释在我国方兴未艾。

根据 Taylor(2003)意象图式是由地标（landmark, LM) 和射体 (trajector, TR) 、及路径(path)三部分组成。 其中的地标是指参照物, 而射体是被定为的实体, 射体 的空间方位并不明确需要以界标为参照, 而地标和射体 的关系则表明了介词的不同意义。

但是事实上, 很多种情况下为了凸显射体地标和路 径并不是很清楚。以介词 for 为例子:

1). He is aiming for the house.

2). My English teacher will leave for Shanghai tomorrow.

3). The boy is too small to reach for the cup on the table.

这三个句子中的路径都不是很清楚, 但是射体运动 的方向是明确的。第一个句子中的“house”, 第二个句子 中的“Shanghai”，第三个句子中的“cup”都是地标，也就 是射体运动的方向，但是这些射体运动的起始点并不明 确, 所以路径并不清楚。

意象图式实际上就是隐喻理论的基础。通过隐喻理 论中意象图式对介词 for 进行进一步的讲解。for一词除 了空间域外还可以延伸到方向域, 目的域, 原因域, 数 量域, 情感域等不同域的认知。

1). He is heading for school. (方向域)

2). He came here for the meeting. (目的域)

3). For the storm, they had to stay in the house. (原因 域）

4). She has lived here for twenty years. (数量域)

5). The woman cares for her son very much. （情感 域）

通过上述隐喻理论的分析, 介词 for 的意思也就一 目了然。

在教学中, 介词由于具有较强的搭配性, 意义比较 复杂, 使用意象图式理论进行讲解一方面会印象深刻, 另一方面会让学习者进行区分, 能够更好地更准确地使 用。如介词“out”, 用意象图式解释, 最基本的意思就 是“出来, 在外面”。

但是在不同的背景下, 意思就不一样了。例如句子 “The moon came out.”与句子“The fire went out.”中的 “out”并不是同一个意思, 那么分别用意象图式如图 1 和 2, 就能表现出 out 在两个句子中的意义不同。

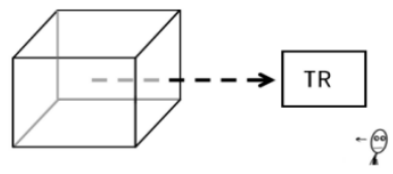

LM

图 1 come out 的意象图式 


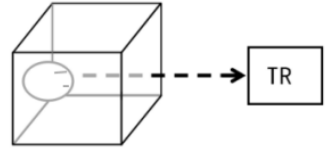

LM

图 2 go out 的意象图式

\section{2 意象图式在解释一词多义中的应用}

在英语中一词多义现象较为常见。一词多义是指 一个词有很多不同但却又相互关联的意义的词。根据 Labove 和 Rosch 提出来的原型范畴理论, 一个词语由 不同的义项构成, 而这些义项有一个核心义项, 也就是 原型(prototype), 其他的义项都是围绕这个原型向周围 延展, 形成了语义网络。

以英语中的“head”为例, 在英语中“head”最核心的 意思就是“人身体最上部或者动物身体最前面的部分” 而围绕这个核心义项, 由此又延伸了更多其他的边缘义 项。由图 3 可以知道 head 的其他引申义。

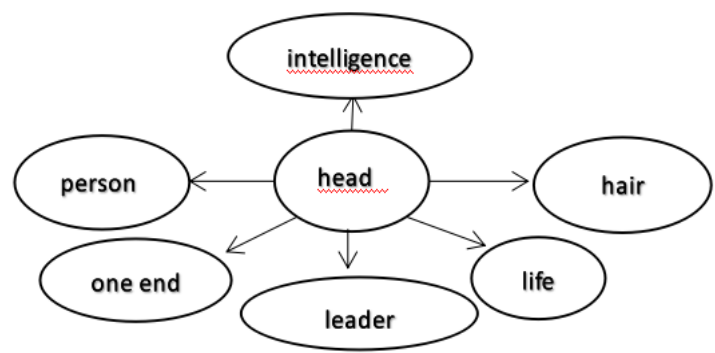

图 3 head 的意象图式

1). He is the head of a school. (他是校长。leader)

2). The young woman is combing her head. (这个年 轻的女人正在梳头。 hair)

3). He has a good head for business. （他非常有经 商头脑。intelligent）

4). He is doing a head count. (他在数人数。person)

5). The deadly shot made him lost his head.（这致命 的一击让他丢了性命。life )

6). He is thinking about where to put the head of the bed. （他在考虑床头要摆放哪。one end）

在英语中有很多词是一词多义, 而这也是让学生们 觉得英语单词难记的原因, 使用意象图式法辅助词汇记 忆会让学生的词汇记忆问题迎刃而解。

\section{3 意象图式在同义词辨析中的应用}

英语中有很多意义相近, 但用法不同的词汇, 这 也成为了学生们学习英语的绊脚石。近义词在英语语言 中占有很大比例, 它们通过词义、用法等方面的相同或 相近构成了庞大复杂的英语词汇体系。(张继东, 2005)
陈芳(2010)使用了意象图式法对 soon, quickly, promptly 三个对于中国学生来说很难区分的词进行了解释。使用 意象图式可以更准确更深刻地对近义词之间的区别用 法进行解释。

在句子 “She walked into the room.” 及句子 “She was in the room.”两个句子中的 into 与 in 是同义介词。 通过图 4 和图 5 两个图式对这两个介词进行讲解, 它们 区别就一目了然了：很明显 in 就是描述的“在里面”的 状态, 而 into 是射体从外部进入到内部的动程。

LM

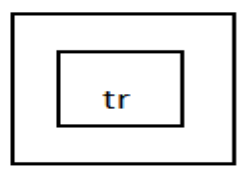

图 4 in 的意象图式

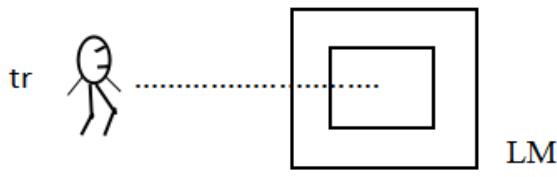

图 5 into 的意象图式

再如 beneath, under, below 都是“在......的下面”, 用言语描述区别印象并不深刻, 有些学生听过几遍仍然 一头雾水。可是如果用意象图式 (如图 6) 来进行解释, 则效果非同凡响。

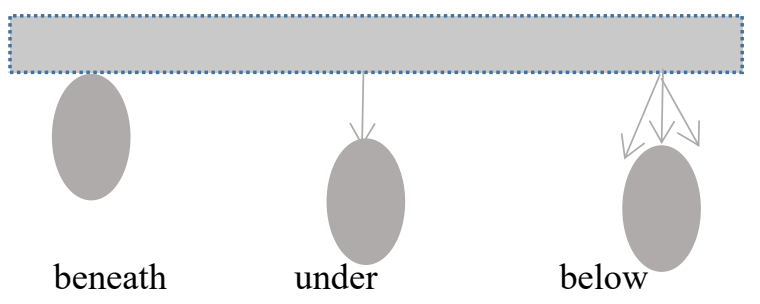

图 6 beneath, under, below 意象图式区别

由图可知 beneath 是紧挨着, 在......的下面, 而 under 是垂直在......的下面, below 是不一定在某物的 垂直下方，范围较广。

使用意象图示法对英语同义词进行辨析, 不但行之 有效而且令人印象深刻, 不失为英语词汇教学的好办 法。

\section{4. 总结}

根据 Allan Paivio 在 1969 年提出的双解码理论 (dual-coding theory), 他认为语言认知过程需要两个语 码处理系统: 语言系统处理和非语言系统处理, 其中非 语言系统处理主要就是对意象和情感的处理。而意象图 
式恰好符合双解码理论, 通过意象图式简图可以更有效 地帮助学习者进行词汇记忆。著名的教育学家杜威所 说, 学习与行为(doing)之间的重要联系, 他强调课堂需 要采用活动方式。并且认为教师如果以毫无生气或者机 械的方式进行授课, 那么这些信息对于学生来说是无用 的“与思考活动无关的信息是死的, 是一种足以扼杀心 智的负担” (J.Dewey, Democracy and Education, 186) 他 还强调学校就是一个社会(community), 学生们不应该 被隔离在书桌之后, 他们需要在沟通中学习, 需要在社 会情境中进行有目的的活动, 需要在共同兴趣的探索 下, 与教师互动, 这才是学习有效性的不二法门。吉布 斯发现, 做动作可以帮助理解与表达与该动作相关单词 的词义, 而有时候这个动作并不需要真正去做, 在头脑 中出现动作意象也可以达到同样的效果。

通过意象图式进行英语词汇教学是一种不同于传 统方式的词汇教学方式, 它不但能够激发学生们的英语 词汇学习热情, 而且能够扩展学生们的意象空间促进师 生之间的互动, 最主要的是它能够更加契合人的认知过 程, 通过意象加深印象, 从而提高英语词汇教学与记忆 的效率。

\section{项目基金}

本论文是 “2019 年度甘肃省普通高等学校英语教 改项目”（项目编号：Y201904），西北民族大学中央 高校项目（项目编号：31920190137）的阶段性成果。

\section{REFERENCES}

[1] Amant, R. St., Morrison, C.T., Chang, Y.H., Cohen, P.R., \& Beal, C. An Image Schema Language. Information Sciences Institute, University of Southern California. 2002.

[2] Brugman, C. The Story of Over[D]. M.A. thesis. Linguistics Dept, University of California, Berkeley, 1981.

[3] Chen, F.Distinguishing Synonymous Adverbs:A Study on Soon, Quickly and Promptly from Cognitive Perspective[J], Journal of Social Science of Jiamusi University, 2010,28(6):167-170.

[4] Chen, X.X., \& Xu, Y. The Effects of the Image-Schema Theory on the Acquisition of the Polysemous Prepositions:On、Over and Above[J], Foreign Language and Their Teaching, 2009, 246 (9) :18-23.

[5] Dewell, R. Over Again: Image-schema Transformations in Semantic Analysis[J]. Cognitive Linguistics, 1994, 5:351-380.

[6] Huang, Y. Z. On the relationship between morphological motivation and lexical acquisition $[\mathrm{J}]$, Foreign Language Teaching and
Research(bimonthly), 2001,33(6):430-435.

[7] Huang, Y.H., \& Bai, J.H. My opinions on the polysemous preposition - taking over as an example[J], Foreign Languages and Their Teaching, 2006, 212(11): 4-7.

[8] Lakoff, G. \& Johnson, M. Metaphor We Live By[M]. Chicago: The University of Chicago Press, 1980.

[9] Lakoff, G. "The Contemporary Theory of Metaphor" in A. Ortony (Eds). Metaphor and Thought[M]. Cambridge University Press, 1993:203-207.

[10] Lakoff, G. Women, Fire and Dangerous Things: What Category Reveal About the Mind[M]. Chicago:Chicago University Press, 1987:416-461.

[11] Li, F.Y. On Image Schema Theory[J], Journal of Sichuan International Studies, 2007, 23(1):80-85.

[12] Lindstromberg, S. Prepositions:meaning and method[J] . ELT Journal, 1996, 50:225-236.

[13] Liu, C.C., \& Wang, H.G. An Image Schematic Analysis on the Preposition From[J], Journal of Xichang University·Social Science Edition, 2019, 31(1):93-96.

[14] Meara, P. "The classical research in L2 vocabulary acquisition". In G.Anderman \& M. Rogers (Eds.), Words, words, words: The translator and the language learner[J], Clevedon: Multilingual Matters. 1996:27-40.

[15] Paivio, A. On the functional significance of imagery[J]. Psychological Bulletin, 1969, 79:1-16.

[16] Piaget, Jean. The language and thought of the child, Routledge, 1988.

[17] Taylor, J.R. Linguistic Categorization: Prototypes in Linguistic Theory. Beijing: Foreign Language Teaching and Research Press, 2003.

[18] Ungerer, F.,\& Schemid, H. An Introduction to Cognitive Linguistics. Beijing: Foreign Language Teaching and Research Press, 2018.

[19] Wang, Y . Cognitive Linguistics[M] . Shanghai Foreign Languages Education Press, 2007.

[20] Xu, W.vA Study of Teaching Strategy of College English Vocabulary under the Image Schema Theory[D] , Ji Lin University Postgraduate's Dissertations, 2016.

[21] Yue, H.P., Xu, Minghui., \& Huang, Yuhan. On Spatial Metaphorical Extensions of Prepositions in, on and at -Based on Image Schema Theory[J], Journal of Changsha University, 2019, 33(6):126-129.

[22] Zhang, J.D., \& Liu, Ping. Corpus- based Approaches to the Differentiation of English Synonyms[ J] .Journal of PLA University of Foreign Languages, 2005 ,(6). 49-52.

[23] Zhang, W.D. Meaning and Cognitive Categorization[M], Cheng Du: Si Chuan University Press, 2007:306.

[24] Zhou, M.Q. Ambiguity and its Interpretation and Utilization[J], Applied Linguistics, 2004, $3: 83-90$ 